\title{
The Peoples of Oiapoque and the Kuahí Museum
}

\section{Available at http://vimeo.com/51218597}

Anthropologist Lux Vidal talks about her work with the indigenous peoples of Oiapoque, who belong to a variety of ethnic groups and her experience at the Kuahí Museum. . In 1998, leaders of those groups asked the Government of the State of Amapá for a museum. Since then, this museum has been a place for mediation and articulation between the indigenous peoples, the State and civil society. The possibility it opened up for conceiving and setting up exhibitions about different themes in indigenous daily life, has been a major force for the Peoples of Oiapoque, and their affirmation of ethnic identity.

Director: Regina Abreu. Interviewee: Lux Vidal. Editor: Luciana Lima. Photographer: Noilton Nunes. Archive Material: Kuahí Museum; Iepé; Museum of Indigenous People (Museu do Índio); Socio-Environmental Institute (Instituto Socioambiental). Music: Povos do Oiapoque. Translator: Luciana Lang. Year of Completion: 2012

A Production by the Laboratory of Memory and Image (Laboratório de Memória e Imagem do PPGMS - LABIM) of the Post-Graduate Program in Social Memory (Programa de Pós-Graduação em Memória Social - PPGMS), Federal University of the State of Rio de Janeiro (Universidade Federal do Estado do Rio de Janeiro - UNIRIO). Supported by the Working Group at the Kuahí Museum, Indigenous Communities of Oiapoque and CNPq - Edital Universal (2010)

Acknowledgements: Lux Vidal. Anne-Courtois-Vidal 